\title{
DETERMINING CHARACTERISTICS OF DIFFERENT FILTER MATERIALS TO REMOVE VOCS (MAINLY FORMALDEHYDE) IN THE BUILDING ENVIRONMENT
}

\author{
Rahul Tiwari \\ Peter the Great St.Petersburg Polytechnic University \\ Polytechnicheskaya ul. 29, St.Petersburg, Russia \\ believeyrself.rt@gmail.com
}

\begin{abstract}
Volatile organic compounds (VOCs) are inseparable part of the building environment. As a result the health and well-being of the occupants is at risk because the concentration of these compounds is often times above the standard levels. As a result the occupants are unknowingly exposed to these harmful compounds. Recently, there have been developments on the ways of solving this problem.

The existing heating, ventilation and air conditioning(HVAC) systems offer a solution but often times have some drawbacks in operation. Some techniques are effective but not very feasible for cleaning indoor air while others are very sophisticated. One of the smart ways to reduce the levels of VOCs in the buildings is to use air filters. VOCs are almost always present indoors; however, their concentration in the ambient air can be controlled by use of air purification process and can be brought down to acceptable levels.

One of the major compounds found in buildings is formaldehyde, which is emitted by substances used daily to day life. In the long run, formaldehyde has adverse health effects on the occupants. The principal focus of this article is to determine and compare the efficiency of different filter materials like granulated carbon, carbon+ion-exchange and ion exchange in removing the major quantified compound i.e. formaldehyde. Also another important criteria in the selection of a filter material is pressure drop, hence the performance of each filter with respect to pressure drop has also been shown.
\end{abstract}

\section{Keywords}

Volatile organic compounds, formaldehyde, heating, ventilation, and air conditioning (HVAC), air filter, ventilation.

\section{Introduction}

Nowadays, environment of buildings has become a topic of main concern as more people are experiencing problems associated with quality of indoor air. This is the reason for a transition of research which was initially focused mainly on outdoor environment contamination to indoor air quality within buildings. Many researches are extensively being conducted to address the issue of quality of indoor environment. People tend to spend most of their time indoors at home, at work or travel.

Despite many regulations are still based on outdoor air pollution with little attention is paid to indoor quality. Hence, its necessary that people are aware of quality of air they are breathing and take appropriate measures to reduce the sources of pollutants. Recent studies have shown that the pollutants in the indoor air are higher than expected.

Since it has been found out that the health related problems are caused by exposure to pollutants overtime, so indoor atmosphere requires more study and understanding. Studies have shown that the contamination of building atmosphere has been linked to several building materials and consumer products that are used in everyday life. Emissions are pronounced in newly built apartments (Jo and Shin, 2012).

In short we are unknowingly polluting our known habitat and eventually breathing in the polluted environment. Our activities have direct impact on temperature, gases, humidity, odor, volatile organic and inorganic gases, and most importantly the particulate matter. 
Although structures are designed to protect people from adverse climate and to provide higher level of comfort but on the contrary we have spoiled this environment and introduced a variety of contaminants into the indoor atmosphere that have a potential to cause moderate to severe health risks. They include inorganic compounds like lead, radon and asbestos and organic compounds like formaldehyde, which is found in higher concentration as compared to other pollutants (Goodman et. al., 2017).

The pollutants of major concern are radon and formaldehyde as they are found in more quantity and therefore can pose grave health problems. The focus of this article is to present the efficiency of different filter materials to remove most quantified organic compound i.e. formaldehyde and also to measure the pressure drop across three different filters.

Volatile organic compounds (VOCs) are the major pollutants in indoor air, which significantly impact indoor air quality and thus adversely affecting human health (Karakitsios et al., 2011). VOCs are the inherent part of the building atmosphere which are generated from indoor sources. They are organic chemicals that have high vapor pressure but low boiling point. This property causes large number of VOCs to evaporate from liquid or solid form and enter into surrounding air. Such a unique behavior is called volatility.

Everything we do in daily life results in the release of organic chemicals to the atmosphere ranging from driving a car, painting the house, cooking, making a fire etc. all of these processes result in the emission of organic compounds such as carbonyls, alcohols, alkanes, alkenes, esters, aromatics, ethers and amides. Studies have shown that formaldehyde is the most frequently quantified compound. It is the best known organic compound found in every building atmosphere.

The contamination of indoor air is common to every built environment. It starts when inhabitants start complains of discomfort, headaches, nausea, dizziness, sore throats, dry or itchy skin, sinus congestion, nose irritation or excessive fatigue. These are only the beginning symptoms and are almost always followed by long term conditions. Sick building relates to the condition that an occupant experiences during the course of his stay in the building. It does not mean that the building is sick and uninhabitable. There have been reports from the occupants who complained about symptoms, such as irritation or dryness of mucous membranes, burning eyes, headache or fatigue.

These symptoms are termed as Sick-BuildingSyndrome (SBS)(Takigawa et al., 2012). A common related problem is Building Related IIIness (BRI). BRI is considered as a building associated, diagnosable disease. If signs of actual illness are present and can be linked to a condition in the facility, the concerned building can be classified as BRI. The key point of difference between Sick building syndrome (SBS) and Building Related IIIness (BRI) is that particular contaminants resulting into SBS may not be known.
VOCs are of utmost importance because they are mainly responsible for causing long term adverse health effects. Studies have also found that some VOCs are even neurotoxic (Fournier et al., 2017, Liu et al., 2008).

Home ventilation plays a significant role in keeping the indoor air clean and to check the level of pollutants. Adequate ventilation facilitates supply of fresh air which also helps in removing the pollutants. But opportunities for ventilation may be limited by weather conditions or by contaminants in the outdoor air. Countries which are located on more northern latitudes have low temperatures which in turn do not allow free natural ventilation.

The efficiency of ventilation for controlling VOC concentrations depends upon the operation of the building, the pollutant sources and the physical and chemical processes affecting the pollutants. Thus, a combination of methods to reduce the concentration is suggested (Fisk, Mirer and Mendell, 2009).

Artificial ventilation in the form of air-ventilation systems are the only viable option. Sometimes the systems are not efficient enough to remove all pollutants. The buildings in cold countries tend to have more closed spaces and have lack of natural ventilation. As a result, air may have more concentration of VOCs (Salthammer 2017).

It has also been observed that presence of organic compounds in buildings, offices and other places of work affect the performance of people using the building. It has also been seen that reducing air pollutants in the buildings is more energy efficient that to provide outdoor supply of air (Salonen et al., 2009).

The quality of working environment with less concentration of pollutants provides satisfaction and increases the productivity of people (Frontczak et al.,2012; Lee and Guerin 2009). A well maintained air cleaning system can help in keeping the air clean and its also necessary to minimize the use of materials that act as a source of pollutants in the buildings.

World health organization classifies organic compounds into the following classes (Table 1).

Table 1. Organic compounds classification into the following classes according to World health organization.

\begin{tabular}{|l|l|l|l|}
\hline Description & Abbreviation & $\begin{array}{l}\text { Boiling Point } \\
\text { range }\end{array}$ & Example \\
\hline $\begin{array}{l}\text { Very volatile } \\
\text { (gaseous) } \\
\text { organic com- } \\
\text { pounds }\end{array}$ & VVOC & $<0$ to 50-100 & $\begin{array}{l}\text { Propane, bu- } \\
\text { tane, methyl } \\
\text { chloride }\end{array}$ \\
\hline $\begin{array}{l}\text { Volatile } \\
\text { organic com- } \\
\text { pounds }\end{array}$ & VOC & $\begin{array}{l}50-100 \text { to } \\
240-260\end{array}$ & $\begin{array}{l}\text { Formalde- } \\
\text { hyde, d-Lim- } \\
\text { onene, tolu- } \\
\text { ene, acetone, } \\
\text { ethanol (ethyl } \\
\text { alcohol) } \\
\text { 2-propanol }\end{array}$ \\
\hline $\begin{array}{l}\text { Semi volatile } \\
\text { organic com- } \\
\text { pounds }\end{array}$ & SVOC & $240-260$ to & $\begin{array}{l}\text { Pesticides }, \\
\text { fire retardants }\end{array}$ \\
\hline
\end{tabular}


Formaldehyde is a volatile organic compound (VOC) found in the building atmosphere emitted from a wide range of building materials and products of daily use (Salthammer, Mentese and Marutzky, 2010).

It belongs to a group of one-carbon saturated aliphatic aldehydes with chemical formula - $\mathrm{HCHO}$. Due to such a molecular structure it is highly reactive with compared to other aldehydes like acetaldehyde, acrolein, glutaraldehyde etc. It is useful in industrial and commercial process because of its high thermal stability. Formaldehyde is a colorless, gaseous substance with a strong, pungent odor.

On condensation it forms a liquid with a high vapor pressure that readily forms a part of the air. Owing to its high reactivity, it rapidly changes to form paraformaldehyde. Hence, liquid formaldehyde must be held at low temperature or mixed with a stabilizer (such as methanol) to prevent/minimize polymerization.

Formaldehyde is commercially available in the form of paraformaldehyde, which has multiple lengths of $\mathrm{HCHO}$ molecules. It is a colorless solid that slowly decomposes and vaporizes into $\mathrm{HCHO}$ at room temperature. It is used in a variety of deodorizing commercial products.

It is also available as formalin, an aqueous solution containing 37 to $38 \% \mathrm{HCHO}$ by weight and the rest 6 to $15 \%$ methanol. For the experiments conducted as a part of this thesis, formalin was used as a source of formaldehyde to have some recordable value with the available devices.

Urea-formaldehyde is a thermosetting resin which is used as adhesives for wood, in the production of pressedwood products such as particle board, medium-density fiber board and hardwood plywood, finish coatings textile treatments and in the production of urea-formaldehyde foam insulation.

Table 2. Primary sources of formaldehyde in indoor environment.

\begin{tabular}{|l|l|}
\hline Products & Examples \\
\hline 1) Combustion & $\begin{array}{l}\text { Cigarettes, e- cigarettes, } \\
\text { kerosene, natural gas,stoves } \\
\text { and fire places, vehicle } \\
\text { exhaust }\end{array}$ \\
\hline 2) Insulation & $\begin{array}{l}\text { Urea formaldehyde foam } \\
\text { insulation (UFFI) }\end{array}$ \\
\hline 3) Pressed-wood products & $\begin{array}{l}\text { Pressed-wood products } \\
\text { Plywood, particle board, dec- } \\
\text { orative paneling }\end{array}$ \\
\hline 4) Daily products & $\begin{array}{l}\text { Deodorants, perfume, cos- } \\
\text { metics, disinfectants, insecti- } \\
\text { cides, paints, dyes, shampoo, } \\
\text { shower gel }\end{array}$ \\
\hline 5) Other sources & $\begin{array}{l}\text { Floor covering, carpet adhe- } \\
\text { sives, fire retardants }\end{array}$ \\
\hline
\end{tabular}

Urea formaldehyde wood adhesives are colorless and provide excellent bonding performance. However, this UF based adhesives is a potential source of free $\mathrm{HCHO}$ into indoor environments, particularly during the first months of usage and later on in the life of a product. Apart from these there are also phenol-formaldehyde resins used in buildings which also a source of $\mathrm{HCHO}$.

Formaldehyde is also found in the deodorants, perfumes and cosmetics which are used on everyday basis (Lefebvre et al., 2012).

Formaldehyde levels in the indoor environment are significantly higher in residential, institutional, and commercial buildings. Pressed wood products are a major source of $\mathrm{HCHO}$ contamination in indoor environments. Particle board is used as underlayment in conventional homes; floor decking, furniture, and a variety of consumer products; and as well as decorative wall panels.

Another type used is hardwood plywood for decorative wall covering and as a part in cabinets, furniture, and wood doors. Medium-density fiber board has been used in cabinet, furniture, and wood door manufacture.

\section{Scope, Objectives and Methodology}

The main objective of the thesis is to find the efficiency of each filter against volatile organic compound (VOC) - formaldehyde and also to find the pressure drop across the three filters namely carbon + ion exchange, carbon only and ion exchange filter and finally make recommendations. To find pressure drop and efficiency, experiments will be conducted separately with each filter installed in the test setup. Its also vitally important to review the past results and research conducted in regard to the purification of indoor air. There are several methods adopted to keep the indoor environment clean and safe for inhabitants. However, these are not widely used over the lack of awareness about the quality of indoor air. A past study research conducted concerning VOCs by using photo catalytic oxidation (Wang, Ang and Tade, 2007). This method is one of the effective methods to control the amount of VOCs. One of the major drawback is that its commercially expensive.

Whenever the use of technology is concerned over a large scale it has to be affordable for the public. But photo catalytic oxidation is rather expensive. Another setback related to this method is the chances formation of carbon monoxide, CO (Pershin et al.,2017) as a byproduct. But since this method uses short-wave ultraviolet light to energize the catalyst, it has an advantage to be cost effective. Another study shows that there is possibility of formation of formaldehyde as result of photo catalytic oxidation. This technology is still on the nascent stage and needs to be optimized.

One more study was conducted to tackle VOCs by using coconut activated carbon shell. The filter was tested for VOCs removal efficiency. It gives promising results for the use of activated carbon filter but this study was focused on the use of one filter and does not make comparison of removal efficiency with respect to other filters, which are sometimes claimed to be effective (Gallego et al., 2013). Similar experimental study was made to remove VOCs using activated carbon-fiber (ACF) filter calcined with copper oxide (CuO) catalyst (Huang et al., 2010). When a choice is to be made while selecting an effective 
filter material it is necessary to give due consideration to parameters like pressure drop and standard removal efficiency of the filter material. This research is focused on the same objective to suggest the best filter in terms of pressure drop and efficiency.

It also possible that the Heating, Ventilating, and Air Conditioning (HVAC) system may promote accumulation of compounds like formaldehyde and acetone. Also, its possible that microorganisms may survive on filters giving rise to those compounds.

The use of electrostatic precipitators is one of the techniques to remove VOCs from indoor air. One study has incorporated the electrostatic precipitator-type small air purifier with a carbon fiber ionizer and an activated carbon fiber filter (Kim et al., 2018). Although it has shown to be efficient in removing the VOCs from the air, on the contrary there are possibilities of formation of ozone in the process, which is harmful to health.

VOCs are found in every human dwellings whether its home, office or shops. Apart from sources that are always present in the building, VOCs are also emitted from equipments used in buildings like printing machines, photocopy machines etc. (Destaillats et al., 2008; Sarkhosh et al.,2012). They are also found in hair saloons (Gennaro et al., 2014).

The one of the best way to analyze the relative performance of various air filters to clean indoor air is to make a comparative study with regard to their efficiency against most quantified and well known VOCs in the building i.e. formaldehyde. Pressure drop helps to choose the filter which offers less resistance to air flow and hence it more effective.

Formaldehyde, which is carcinogenic, is very harmful to human health. Hence, it is important to give more attention for removal of this compound from the building. Also, it is also possible to make recommendation and suggest practical implication of the results obtained from the experiments.

\section{Methods}

\section{General set up}

As shown in Figure 1, $\mathrm{Pd}$ is the pressure drop (in pascals, $\mathrm{Pa}$ ) and $\mathrm{Ps}$ is the measured concentration of formaldehyde measured by gas analyzer (in milligram/ $\mathrm{m}^{3}$ ). The diameter of duct, used as passage for air flow, was $250 \mathrm{~mm}$. Small hole was made at equidistance in the input duct and the output duct to measure the pressure drop, velocity using differential manometer.

The change in air flow was created using combination of two devices namely frequency regulator and fan. By selecting different frequency values in the control panel of frequency regulator it was possible to create different velocity of flow. The filter was placed in the rectangular chamber to carry out the experiment.

\section{Filter materials}

For conducting the experiments, three different types of filter material were used. All readings were taken separately with each filter installed. Carbon and Ion exchange is a filter with carbon granules and ion exchange material in the form layers which imparts property of ion exchange material. Another filter material was carbon. The size of carbon granules was $4 \mathrm{~mm}$ in diameter with density $550 \mathrm{gm} /$ decimeter $^{3}$.

The ion exchange filter used was Panion 510, which is capable of removing organic compounds like formaldehyde, acetone, oxides of sulphur, benzene, tobacco smoke, organic acids and many other harmful compounds found in homes.

For conducting experiments, Sovplym laboratory, Industrialniy prospect was used.

The experiment involved the use of following:

1) Formalin - It's a solution containing $40 \%$ formaldehyde or $37 \%$ by mass. Since its highly volatile so it was used as a source of formaldehyde. It is very important to note that formaldehyde is certainly found in homes however the concentration is small. In order to successfully conduct experiments it was necessary to use an actual source of formaldehyde so that the gas analyzer is able to detect the presence of formaldehyde.

2) Gas analyzer - It is a device used for analyzing the presence of organic compounds in the air. It is able to record the concentration of carbon monoxide, sulphur dioxide, hydrogen sulphide, ammonia and organic compounds like formaldehyde and acetone. Gas analyzer used was geolan-1p.

3) Frequency regulator - It is used to vary the speed of the fan and in turn the air flow. It comes with a control panel giving option to select different frequencies. For the experiment the range of frequency was 20 to 50 hertz. It



Figure 1. Experimental setup (set, installation) 
was connected to the fan and hence its possible to get different air flow through the duct.

The objectives of conducting experiments are:

1) To find pressure drop across three filters viz. carbon and ion exchange, carbon and ion exchange filter. In HVAC system, if a filter is installed, it will create some resistance to the air flow. This resistance results into pressure drop. The difference in air pressure on one side of filter versus other side is termed as pressure drop across a given filter. If there is more pressure drop, it indicates that there is too much resistance to air flow. This wastes energy and increases wear and tear. The aim is always to minimize pressure drop. In order to measure pressure drop, Testo 510 which is a differential manometer was used.

2) To find efficiency of each filter in removing formaldehyde. For each filter three readings were taken. Then, the final value of efficiency was calculated as an average of the three values. Then to check the result comparison was made. The first reading was taken before air passes through filter using gas analyzer and final value was recorded after the filter when air has been filtered out. Same process was repeated for each of the filter.

Efficiency $=\frac{\text { Initial value }- \text { Final value }}{\text { Initial value }} \times 100$

\section{Results and discussions}

The results are listed in the Table 3 and 4.
Table 3. Measuring instruments used in testing

\begin{tabular}{|l|l|l|l|l|}
\hline № & $\begin{array}{l}\text { Name of the } \\
\text { measuring } \\
\text { instrument }\end{array}$ & $\begin{array}{l}\text { Account serial } \\
\text { number }\end{array}$ & $\begin{array}{l}\text { Certificate } \\
\text { number } \\
\text { about veri- } \\
\text { fication }\end{array}$ & $\begin{array}{l}\text { Validity of } \\
\text { verification }\end{array}$ \\
\hline 1 & $\begin{array}{l}\text { Differential } \\
\text { pressure } \\
\text { gauge digital } \\
\text { Testo 510 }\end{array}$ & $38966834 / 012$ & 0126441 & 23.08 .2018 \\
\hline 2 & Pitot tube & 52 & $1528-2016$ & 02.08 .2018 \\
\hline
\end{tabular}

Table 4. Technical data on test equipment

\begin{tabular}{|l|l|l|l|l|}
\hline \multirow{2}{*}{ Fan } & Type & \multicolumn{2}{|l|}{ Diameter of duct, mm } & $\begin{array}{l}\text { Rotation } \\
\text { frequency, } \\
\text { min -1 }\end{array}$ \\
\cline { 2 - 5 } & FS-4000 & \multicolumn{2}{|c|}{$\varnothing 250$} & 2850 \\
\hline $\begin{array}{l}\text { Electro- } \\
\text { motor }\end{array}$ & Power, kW & Voltage, V & $\begin{array}{l}\text { Nominal } \\
\text { current, A }\end{array}$ & $\begin{array}{l}\text { Rotation } \\
\text { frequency, } \\
\text { min -1 }\end{array}$ \\
\cline { 2 - 5 } & 1.5 & 380 & 3.46 & 2850 \\
\hline
\end{tabular}

Efficiency-All values in milligram $/ \mathrm{m}^{3}$. For measurement of efficiency the volume of flow was kept constant. It was kept at $1200 \mathrm{~m} 3 / \mathrm{hr}$ for recording the values of efficiency for all three filters. Here, Ps represents concentration of formaldehyde measured before and after filtration.

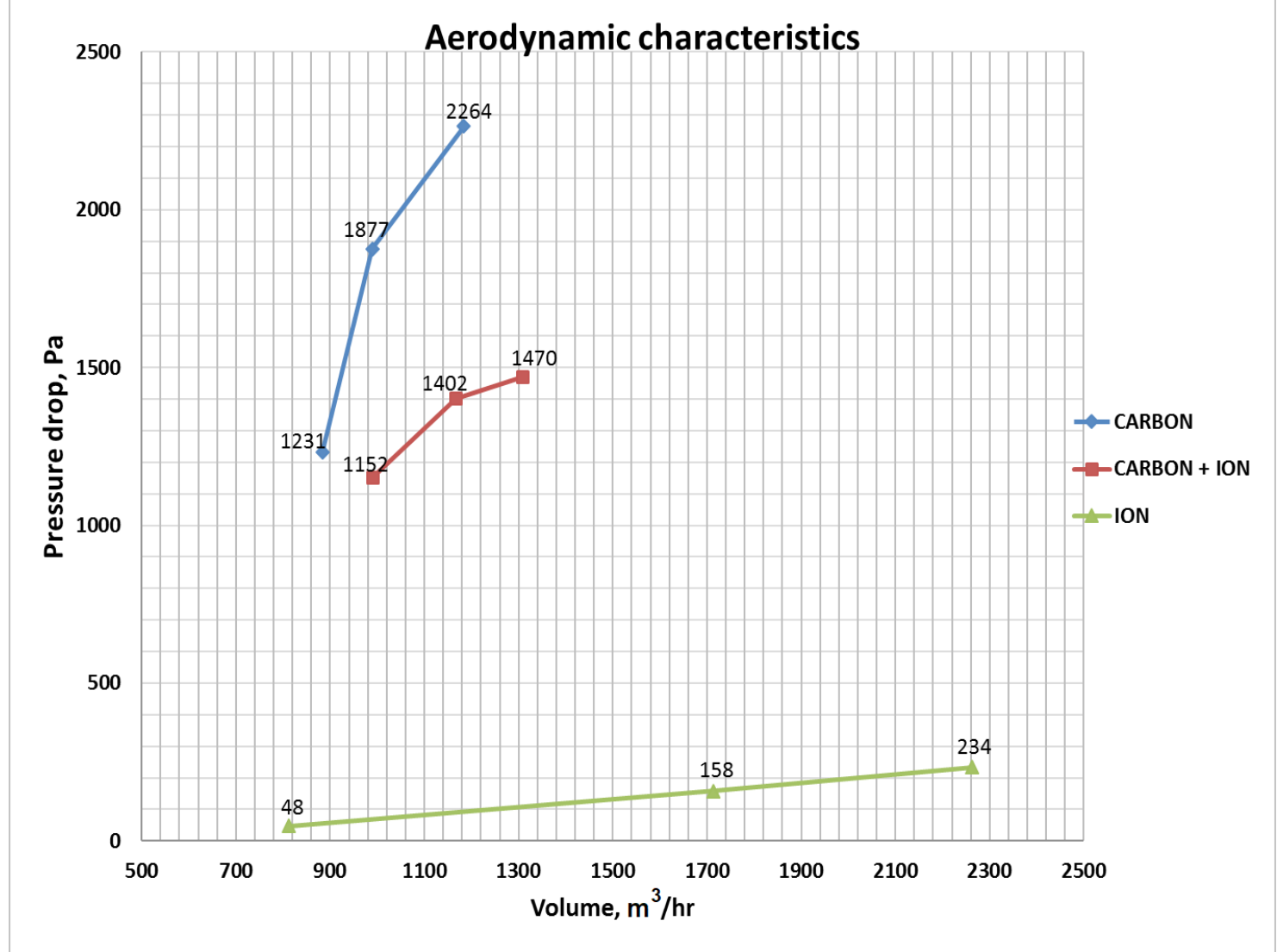

Figure 2. Pressure drop 


\section{Architecture and Engineering Volume 3 Issue 2}

Table 5. Aerodynamic performance with carbon+ion exchange filter

\begin{tabular}{|c|c|c|c|c|c|c|}
\hline Frequency & Velocity & Average velocity & Volume flow & $\begin{array}{l}\text { Pressure }(\mathrm{Pd}) \text { before } \\
\text { filter in pascals }(\mathrm{Pa})\end{array}$ & $\begin{array}{l}\text { Pressure }(\mathrm{Pd}) \\
\text { after filter in } \\
\text { pascals }(\mathrm{Pa})\end{array}$ & $\begin{array}{l}\text { Difference in pres- } \\
\text { sure in pascals }(\mathrm{Pa}) \\
\mathrm{dPs}, \mathrm{Pa}\end{array}$ \\
\hline $\mathrm{v}, \mathrm{Hz}$ & $\mathrm{V}, \mathrm{m} / \mathrm{s}$ & $\mathrm{m} / \mathrm{s}$ & $\mathrm{L}, \mathrm{m}^{3} / \mathrm{h}$ & $\mathrm{Ps}, \mathrm{Pa}$ & $\mathrm{Ps}, \mathrm{Pa}$ & $\mathrm{dPs}, \mathrm{Pa}$ \\
\hline \multirow[t]{3}{*}{36} & 4.5 & \multirow[t]{3}{*}{5.6} & \multirow[t]{3}{*}{989.5} & \multirow[t]{3}{*}{38} & \multirow[t]{3}{*}{1190} & \multirow[t]{3}{*}{1152} \\
\hline & 7.7 & & & & & \\
\hline & 4.8 & & & & & \\
\hline \multirow[t]{3}{*}{40} & 7 & \multirow[t]{3}{*}{6.6} & \multirow[t]{3}{*}{1166.2} & \multirow[t]{3}{*}{48} & \multirow[t]{3}{*}{1450} & \multirow[t]{3}{*}{1402} \\
\hline & 8.5 & & & & & \\
\hline & 4.5 & & & & & \\
\hline \multirow[t]{3}{*}{45} & 6.5 & \multirow[t]{3}{*}{7.4} & \multirow[t]{3}{*}{1307.6} & \multirow[t]{3}{*}{50} & \multirow[t]{3}{*}{1520} & \multirow[t]{3}{*}{1470} \\
\hline & 7.2 & & & & & \\
\hline & 8.5 & & & & & \\
\hline
\end{tabular}

Table 6. Aerodynamic performance with carbon filter

\begin{tabular}{|c|c|c|c|c|c|c|}
\hline Frequency & Velocity & Average velocity & Volume flow & $\begin{array}{l}\text { Pressure }(\mathrm{Pd}) \text { before } \\
\text { filter in pascals }(\mathrm{Pa})\end{array}$ & $\begin{array}{l}\text { Pressure }(\mathrm{Pd}) \\
\text { after filter in } \\
\text { pascals }(\mathrm{Pa})\end{array}$ & $\begin{array}{l}\text { Difference in pres- } \\
\text { sure in pascals }(\mathrm{Pa}) \\
\mathrm{dPs}, \mathrm{Pa}\end{array}$ \\
\hline $\mathrm{v}, \mathrm{Hz}$ & $\mathrm{V}, \mathrm{m} / \mathrm{s}$ & $\mathrm{m} / \mathrm{s}$ & $\mathrm{L}, \mathrm{m}^{3} / \mathrm{h}$ & $\mathrm{Ps}, \mathrm{Pa}$ & $\mathrm{Ps}, \mathrm{Pa}$ & $\mathrm{dPs}, \mathrm{Pa}$ \\
\hline \multirow[t]{3}{*}{36} & 4.6 & \multirow[t]{3}{*}{5.0} & \multirow[t]{3}{*}{883.5} & \multirow[t]{3}{*}{24} & \multirow[t]{3}{*}{1255} & \multirow[t]{3}{*}{1231} \\
\hline & 5.9 & & & & & \\
\hline & 4.6 & & & & & \\
\hline \multirow[t]{3}{*}{45} & 5.4 & \multirow[t]{3}{*}{5.6} & \multirow[t]{3}{*}{989.5} & \multirow[t]{3}{*}{43} & \multirow[t]{3}{*}{1920} & \multirow[t]{3}{*}{1877} \\
\hline & 5.6 & & & & & \\
\hline & 5.9 & & & & & \\
\hline \multirow[t]{3}{*}{50} & 6.7 & \multirow[t]{3}{*}{6.7} & \multirow[t]{3}{*}{1183.9} & \multirow[t]{3}{*}{48} & \multirow[t]{3}{*}{2310} & \multirow[t]{3}{*}{2264} \\
\hline & 6.9 & & & & & \\
\hline & 6.5 & & & & & \\
\hline
\end{tabular}

Table 7. Aerodynamic performance with ion exchange filter

\begin{tabular}{|c|c|c|c|c|c|c|}
\hline Frequency & Velocity & Average velocity & Volume flow & $\begin{array}{l}\text { Pressure }(\mathrm{Pd}) \text { before } \\
\text { filter in pascals }(\mathrm{Pa})\end{array}$ & $\begin{array}{l}\text { Pressure }(\mathrm{Pd}) \\
\text { after filter in } \\
\text { pascals }(\mathrm{Pa})\end{array}$ & $\begin{array}{l}\text { Difference in pres- } \\
\text { sure in pascals }(\mathrm{Pa}) \\
\mathrm{dPs}, \mathrm{Pa}\end{array}$ \\
\hline $\mathrm{v}, \mathrm{Hz}$ & $\mathrm{V}, \mathrm{m} / \mathrm{s}$ & $\mathrm{m} / \mathrm{s}$ & $\mathrm{L}, \mathrm{m}^{3} / \mathrm{h}$ & $\mathrm{Ps}, \mathrm{Pa}$ & $\mathrm{Ps}, \mathrm{Pa}$ & $\mathrm{dPs}, \mathrm{Pa}$ \\
\hline \multirow[t]{3}{*}{25} & 4.4 & \multirow[t]{3}{*}{4.6} & \multirow[t]{3}{*}{812.8} & \multirow[t]{3}{*}{17} & \multirow[t]{3}{*}{65} & \multirow[t]{3}{*}{48} \\
\hline & 4.8 & & & & & \\
\hline & 4.7 & & & & & \\
\hline \multirow[t]{3}{*}{30} & 9.6 & \multirow[t]{3}{*}{9.7} & \multirow[t]{3}{*}{1714} & \multirow[t]{3}{*}{96} & \multirow[t]{3}{*}{254} & \multirow[t]{3}{*}{158} \\
\hline & 9.8 & & & & & \\
\hline & 9.7 & & & & & \\
\hline \multirow[t]{3}{*}{35} & 12.7 & \multirow[t]{3}{*}{12.8} & \multirow[t]{3}{*}{2261.8} & \multirow[t]{3}{*}{156} & \multirow[t]{3}{*}{390} & \multirow[t]{3}{*}{234} \\
\hline & 12.6 & & & & & \\
\hline & 13.2 & & & & & \\
\hline
\end{tabular}


1) Carbon.

Table 8. Efficiency for carbon filter

\begin{tabular}{|l|l|l|l|}
\hline № & $\begin{array}{l}\text { Initial concentration } \\
\text { before filtration, Ps }\end{array}$ & $\begin{array}{l}\text { Final concentration } \\
\text { after filtration, Ps }\end{array}$ & Efficiency \\
\hline 1 & 110 & 44 & 60 \\
\hline 2 & 108 & 40 & 62.9 \\
\hline 3 & 105 & 34 & 67.6 \\
\hline
\end{tabular}

Average efficiency $=63.5 \%$

2) Carbon $+I O N$.

Table 9. Efficiency for carbon+ion filter

\begin{tabular}{|l|l|l|l|}
\hline № & $\begin{array}{l}\text { Initial concentration } \\
\text { before filtration, Ps }\end{array}$ & $\begin{array}{l}\text { Final concentration } \\
\text { after filtration, Ps }\end{array}$ & Efficiency \\
\hline 1 & 122 & 25 & 79.5 \\
\hline 2 & 140 & 36 & 74.2 \\
\hline 3 & 138 & 24 & 82.6 \\
\hline
\end{tabular}

Average efficiency $=78.7 \%$

3) lon-exchange.

Table 10. Efficiency for ion-exchange filter

\begin{tabular}{|l|l|l|l|}
\hline № & $\begin{array}{l}\text { Initial concentration } \\
\text { before filtration, Ps }\end{array}$ & $\begin{array}{l}\text { Final concentration } \\
\text { after filtration,Ps }\end{array}$ & Efficiency \\
\hline 1 & 102 & 21 & 79.4 \\
\hline 2 & 152 & 26 & 82.8 \\
\hline 3 & 97 & 18 & 81.4 \\
\hline
\end{tabular}

Average efficiency $=81.2 \%$

\section{Conclusions}

Based on the experiments conducted, following conclusions can be drawn:

1) Pressure drop is important criteria for choice of the filter. If filter has more pressure drop, it is not very efficient and results into more wear and tear of the filter. Also, more energy is consumed as a part of the filtration process which is not desirable. Hence, it is preferable to choose a filter with lowest pressure drop. From the performed experiments (Figure 2), filter with lowest pressure drop is ion-exchange and therefore its more efficient.

2) Filters used were able to remove the targeted organic compound i.e. formaldehyde. As seen from the tables 4,5 and 6 , filter with highest efficiency is ion exchange filter $(81.2 \%)$, followed by carbon+ion exchange $(78.7 \%)$ and finally carbon with efficiency $63.5 \%$.

3) Although organic compounds are almost invariably present in the ambient air, their true detection is possible through the use of sophisticated methods.

4) Air flow also affects the efficiency of filter and energy consumption. More the air flow, more will be the filtered compounds and particulates reducing effectiveness of filter to some degree. At the same time for higher air flow more power is consumed, which is not desirable.

5) In order to get recordable concentration of formaldehyde captured by the filter, it was necessary to use formalin as a source of formaldehyde. The use of filter will be beneficial in the long run that is, the filter will be able to remove generated formaldehyde and also other organic compounds from the household sources, printing press, offices etc.

6) In order to achieve acceptable indoor quality, mere ventilation is not enough. It is necessary to use an effective filter material like ion-exchange to trap the impurities in the air as a part of the HVAC system. This is essential if intensity of activities is more in the building. In addition, it is recommended to use a pre-filter to trap the particles of larger sizes, so as to increase life of the filter.

7) lon-exchange filter can be used in HVAC system to solve the problem of organic compounds emissions in offices and residential places. This can be facilitated by periodic circulation of the indoor air through the filter. Similarly, in homes HVAC system of smaller capacity can be installed to tackle problem of organic compounds.

8) The use of lon exchange filter will be particularly useful in cold countries where natural ventilation is restricted because of cold weather conditions resulting in closed spaces. Hence, to achieve the desired objective for better indoor environment some source control measures in addition to use of filter will be more effective.

\section{Acknowledgements}

1) I'm grateful to Mr. Mikhail Kitain - Supervisor, who supported and guided me through the experiments.

2) The experiments were conducted at the laboratory of JSC "SovPlym", Revolution Highway 102/2, 195279, St.Petersburg, Russia. I'm thankful to the staff involved in arranging the entire experiment and allowing me to use all the devices and equipments. 


\section{References}

Destaillats, H. et al. (2008). Indoor pollutants emitted by office equipment: A review of reported data and information needs. Atmospheric Environment, 42 (7), pp. 1371-1388. DOI: 10.1016/j.atmosenv.2007.10.080

Fisk, W.J., Mirer, A.G., Mendell, M.J. (2009). Quantitative relationship of sick building syndrome symptoms with ventilation rates. Indoor air, 19 (2), pp. 159-165. DOI: 10.1111/j.1600-0668.2008.00575.x

Fournier, F. et al. (2017). Relative toxicity for indoor semi volatile organic compounds based on neuronal death. Toxicology Letters, 279, pp. 33-42. DOI: 10.1016/j.toxlet.2017.07.875

Frontczak, M. et al. (2012). Quantitative relationships between occupant satisfaction and satisfaction aspects of indoor environmental quality and building design. Indoor air, 22 (2), pp. 119-131. DOI: 10.1111/j.1600-0668.2011.00745.x

Gallego, E. et al. (2013). Experimental evaluation of VOC removal efficiency of a coconut shell activated carbon filter for indoor air quality enhancement. Building and Environment, 67, pp. 14-25. DOI: 10.1016/j.buildenv.2013.05.003

Gennaro, G. et al. (2014). Indoor air quality in hair salons: Screening of volatile organic compounds and indicators based on health risk assessment. Atmospheric Environment, 83, pp. 119-126. DOI: 10.1016/j.atmosenv.2013.10.056

Goodman, N.B. et al. (2017). Volatile organic compounds within indoor environments in Australia. Building and Environment, 122, pp. 116-125. DOI: 10.1016/j.buildenv.2017.05.033

Huang, Y. et al. (2010). Improved Removal of Indoor Volatile Organic Compounds by Activated Carbon Fiber Filters Calcined with Copper Oxide Catalyst. Clean soil air water, 38 (11), pp. 993-997. DOI: 10.1002/clen.200900302

Jo, W.K., Shin, S.H. (2012). Volatile organic compound concentrations, emission rates, and source apportionment in newly-built apartments at pre-occupancy stage. Chemosphere, 89 (5), pp. 569-578. DOI: 10.1016/j.chemosphere.2012.05.054

Karakitsios, S.P. et al. (2011). Exposure to major volatile organic compounds and carbonyls in European indoor environments and associated health risk. Environment International, 37 (4), pp. 743-765. DOI: 10.1016/j.envint.2011.01.005

Kim, M. et al. (2018). A novel electrostatic precipitator-type small air purifier with a carbon fiber ionizer and an activated carbon fiber filter. Journal of Aerosol Science, 117, pp. 63-73. DOI: 10.1016/j.jaerosci.2017.12.014

Lee, Y.S., Guerin, D.A. (2009). Indoor Environmental Quality Related to Occupant Satisfaction and Performance in LEED certified Buildings. Indoor and built environment, 18 (4), pp. 293-300. DOI: 10.1177/1420326X09105455

Lefebvre, M.A. et al. (2012). Consumer inhalation exposure to formaldehyde from the use of personal care products/cosmetics. Regulatory Toxicology and Pharmacology, 63 (1), pp. 171-176. DOI: 10.1016/j.yrtph.2012.02.011

Liu, Y. et al. (2008). Source profiles of volatile organic compounds (VOCs) measured in China Part I. Atmospheric Environment, 42 (25), pp. 6247-6260. DOI: 10.1016/j.atmosenv.2008.01.070

Pershin, A.A. et al. (2017). $\mathrm{TiO}_{2}$ mediated photocatalytic oxidation of volatile organic compounds: Formation of $\mathrm{CO}$ as a harmful by-product. Applied Catalysis B: Environmental, 200, pp. 503-513. DOI: 10.1016/j.apcatb.2016.07.044

Salonen, H. et al. (2009). Volatile organic compounds and formaldehyde as explaining factors for sensory irritation in office environments. Journal of Occupational and Environmental Hygiene, 6 (4), pp. 239-247. DOI: 10.1080/15459620902735892

Salthammer, T. (2017). The Air that I Breathe. Chemie, 51 (5), pp. 308-323. DOI: 10.1002/ciuz.201700779

Salthammer, T., Mentese, S., Marutzky, R. (2010). Formaldehyde in the Indoor Environment. Chemical reviews, 110 (4), pp. 2536-2572. DOI: 10.1021/cr800399g

Sarkhosh, M. et al. (2012). Indoor contaminants from Hardcopy Devices: Characteristics of VOCs in photocopy centers. Atmospheric Environment, 63, pp. 307-312. DOI: 10.1016/j.atmosenv.2012.09.058

Takigawa, T. et al. (2008). Symptom definitions for SBS (sick building syndrome) in residential dwellings. International Journal of Hygiene and Environmental Health, 211 (1-2), pp. 114-120. DOI: 10.1016/j.ijheh.2007.03.004

Wang, S., Ang, H.M., Tade, M.O. (2007). Volatile organic compounds in indoor environment and photo catalytic oxidation: State of the art. Environment International, 33 (5), pp. 694-705. DOI: 10.1016/j.envint.2007.02.011 